\title{
Aplikasi Sasaran Kerja Pegawai (SKP) Pada Dinas Penanaman Modal Dan Pelayanan Terpadusatu Pintu Provinsi Papua Barat Berbasis Visual Basic.Net
}

\author{
Nur Hidayatullah Ahmad ${ }^{1}$, Kristia Yuliawan ${ }^{2}$ \\ Jurusan Teknik Informatika Universitas Papua \\ k.yuliawan@unipa.ac.id
}

\begin{abstract}
Abstrak - Penataan data dan informasi aktivitas kantor secara teratur dan berkesinambungan tidak hanya membuat data dan informasi tersebut menjadi rapi dan teratur tetapi juga akan sangat berguna bagi kantor itu sendiri dalam melakukan evaluasi serta menentukan tolak ukur antara aktivitas yang telah di laksanakan dengan aktivitas yang akan di laksanakan di masa yang akan datang. Meskipun metode tersebut telah di terapkan secara komputerisasi namun aplikasi yang digunakan masih terbatas pada penggunaan aplikasi perkantoran yang umum digunakan misalnya Ms. Office Excel dimana penggunaannya masih sangat banyak memakan waktu ketika melakukan pendataan SKP. Tingkat kesalahan dalam melakukan pembuatan SKP juga menjadi tidak terkendali yang mana hal tersebut membuat informasi yang di simpan menjadi tidak akurat sehingga proses yang dilakukan akan menjadi tidak maksimal. Selain hal tersebut di atas, keamanan data juga menjadi hal yang kurang di perhatikan karena data yang telah di input dapat diubah oleh siapapun juga yang dapat meng-akses komputer tempat dimana data tersebut di simpan. Aplikasi Sasaran Kerja Pegawai (SKP) merupakan sebuah solusi untuk menyelasaikan permasalan diatas. Hasil pembahasan yang diperoleh dari aplikasi ini adalah efesiensi waktu dalam memasukkan data, menyimpan, menyunting, mencari dan menata data SKP secara komputerisasi tanpa mengesampingkan aspek keamanan data, aplikasi ini juga memberikan metode pengamanan akses data dengan menghadirkan hak akses data untuk Pengguna yang berbeda - beda menurut kegunaanya sebagai pengguna aplikasi ini.
\end{abstract}

Kata kunci : SKP, Pegawai, Penilai, Aplikasi Sasaran Kerja Pegawai, Basis Data, Visual Basic.Net.

\section{PENDAhuluan}

Penilaian prestasi kerja merupakan serangkaian proses manajemen kerja yang berawal dari proses penilaian kerja pegawai dengan penyusunan perencanaan prestasi kerja yang berupa SKP (Sasaran kerja Pegawai) kemudian penetapan tolak ukur yang meliputi aspek kuantitas, kualitas dan waktu beserta orientasi pelayanan pegawai. Pelaksanaan penilaian SKP dilakukan dengan cara membandingkan antara realisasi kerja dengan target yang telah dilaksanakan.

Dalam melakukan penilaian, analisis dilakukan terhadap pelaksanaan pekerjaan untuk mendapatkan kerja pegawai agar menyusun rencana perbaikan yang lebih baik lagi setiap tahunannya serta menetapkan hasil penilaian pada SKP untuk memperoleh hasil kerja pegawai. Penilaian prestasi kerja menggunakan parameter penilaian berupa hasil kerja yang nyata dari visi, misi serta tujuan organisasi yang telah ditetapkan pada Dinas Penanaman Modal dan Pelayanan Terpadu Satu Pintu Provinsi Papua Barat.

Dalam melakukan penilaian, proses penilaian SKP pada dinas penanaman modal dan pelayanan terpadu satu pintu provinsi Papua Barat masih menggunakan aplikasi Microsoft Excel dalam membuat SKP (Sasaran Kerja Pegawai) yang dilaporkan kepada pimpinan untuk diketahui dan menyetujui dalam bentuk hardcopy disetiap akhir tahun. Oleh sebab itu, penelitian ini menghasilkan aplikasi untuk memudahkan dalam melakukan input data SKP dengan menggunakan Microsoft Visual Basic.Net. Dengan adanyan aplikasi ini baik menginput, menyimpan, menyunting, mecari dan menata data SKP yang dilaksanakan oleh aplikasi dengan diiringi oleh keamanan data sehingga dapat memberikan kemudahan dan keamanan bagi pegawai dan admin dalam mengakses data SKP secara efektif dan efesien.

\section{METODE PENELITIAN}

1. Metode Pengumpulan Data

Dalam melakukan penelitian, teknik pengumpulan data merupakan faktor yang sangat penting demi keberhasilan penelitian, motode yang digunakan penulis sebagai berikut : a. Studi Pustaka

Metode ini dilakukan untuk mendapatkan sumber-sumber kajian, landasan teori, pengumpulan data, informasi pengolahan data,penarikan kesimpulan, saran dan impikasinya sebagai penyusunan penulisan

b. Studi Lapangan

Metode dilakukan dengan teknik pengamatan langsung atau peninjauan secara cermat di lapangan atau lokasi penelitian. Pada tahap ini dilakakukan dengan melihat langsung kegiatan penilaian SKP yang dilaksanakan oleh Dinas Penanaman Modal dan Pelayanan Terpadu Satu Pintu Provinsi Papua Barat dalam melakukan penginpuatan data, menyimpan, menyunting, mencari dan menata data SKP.

c. Wawancara

Wawancara ini dilakukan dengan mengumpulkan datadata dan informasi dengan cara interview atau wawancara yang dilakukan langsung bersama Admin atau pegawai pada Dinas Penanaman Modal dan Pelayanan Terpadu Satu Pintu Provinsi Papua Barat dengan tujuan untuk mengetahui permasalahan dan pengolahan data SKP.

2. Metode Pengembangan Sistem

Dalam proses pengembangan perangkat lunak, penulis mengunakan metode pengembangan system model Sekuensial Linear atau biasa disebut dengan metode pengembangan air terjun ( metode waterfall), model pendekatan pengembangan system ini adalah model yang umum digunakan. Model ini mengusulkan sebuah pendekatan pengembangan secara sistematik dan sekunsial yang dimulai pada tingkat dan kemajuan system pada seluruh analisis, desain, implementasi dan pengujian dan penerapanya. 


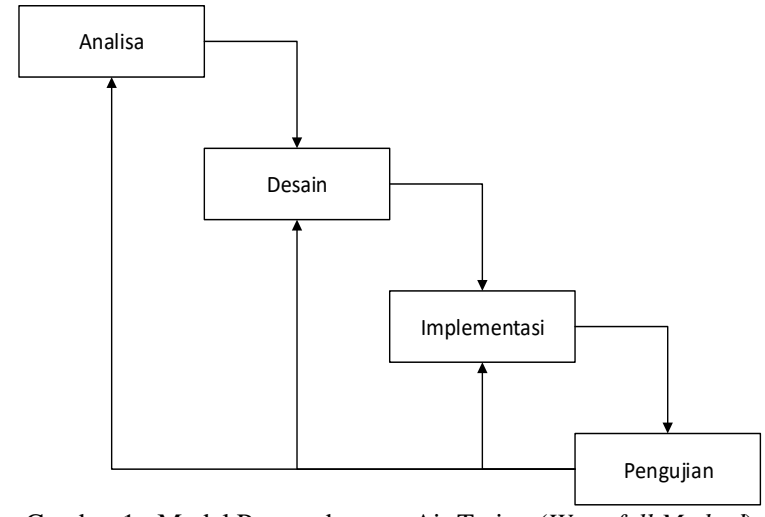

Gambar 1 : Model Pengembangan Air Terjun (Waterfall Method)

1. Analisa

\section{HASIL DAN PEMBAHASAN}

a. Prosedur Sasaran Kerja Pegawai

Analisis sistem Berjalan merupakan gambaran tentang analisa system yang saat ini sedang berjalan di kantor Dinas Penanaman Modal Pelayanan Terpadu Satu Pintu Provinsi Papua Barat pada bagian umum dan kepegawaian. Adapun standar prosedur pelayanan sasaran kerja pegawai dapat digambarkan sebagai berikut :

Tabel 1 : Prosedur pelaksanaan SKP

\begin{tabular}{|c|c|c|c|c|c|c|c|}
\hline \multirow[b]{2}{*}{ No } & \multirow[b]{2}{*}{ Aktiritas } & \multicolumn{3}{|c|}{ Pelaksana } & \multicolumn{2}{|c|}{ Mutu Baku } & \\
\hline & & \begin{tabular}{|l|} 
Subbag. \\
Kepeganaian
\end{tabular} & Peganai & $\begin{array}{l}\text { Pejabat } \\
\text { Penilai }\end{array}$ & Persyaratan & Output & Keterangan \\
\hline 1 & $\begin{array}{l}\text { Membenkian formulir Sasaran Kerja Pegawai } \\
\text { (SKP) kepada para Hakim dan Pegawai. }\end{array}$ & & & & Fomulir SKP & Fomulit SKP & \\
\hline 2 & $\begin{array}{l}\text { Menerima dan mengisi formulir Sasaran Kerja } \\
\text { Pegawai (SKP) }\end{array}$ & & & & Fomulir SKP & Fomulir SKP & \\
\hline 3 & Pengetikan Sasaran Keja Pegawai (SKP) & & & Tidak & $\begin{array}{l}\text { 1. } \\
\begin{array}{l}\text { 2. } \\
\text { Somporter } \\
\text { SKP }\end{array}\end{array}$ & Draft SKP & \\
\hline 4 & $\begin{array}{l}\text { Koreksi atau persetujuan draf Sasaran Kegja } \\
\text { Pegawai. }\end{array}$ & & & & Draft SKP & Draft SKP & \\
\hline 5 & $\begin{array}{l}\text { Menanda tangani formulir Sasaran Kerja } \\
\text { Pegawai yang sudah disetujui. }\end{array}$ & & & & SKP & \begin{tabular}{|l|} 
SKP yang \\
telah \\
ditandatangan
\end{tabular} & \\
\hline 6 & $\begin{array}{l}\text { Mengarsipkan file SKP ke dalam ordner } \\
\text { masing-masing Pegawai. }\end{array}$ & & & & \begin{tabular}{|ll} 
SKP & yang \\
telah &
\end{tabular} & Arsip & \\
\hline
\end{tabular}

\section{Design}

a. Diagram Konteks

Konteks Diagram menggambarkan aliran sistem keseluruhan dimana ada tiga entitas yaitu Sekretaris, Sub. Bagian Umum dan Kepegawaian, Staf Bagian Umum dan Kepegawaian. Dimana Sub.

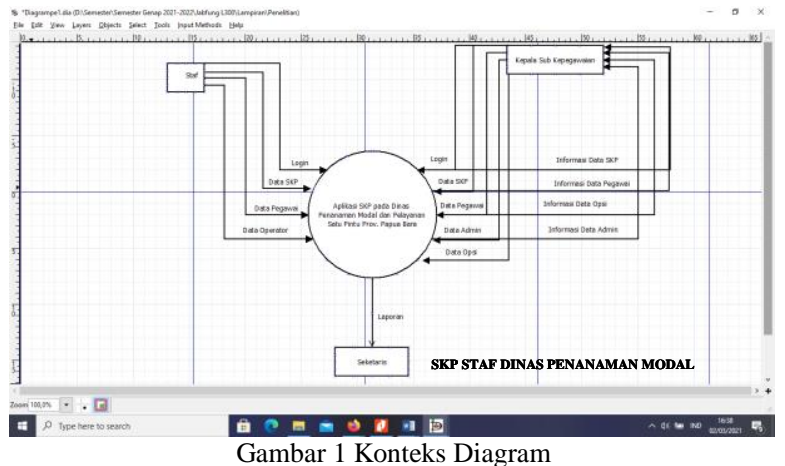

b. Bagan Berjenjang

Untuk dapat mengetahui alur data apa saja yang terdapat pada bagan berjenjang dapat di lihat pada dibawah ini.

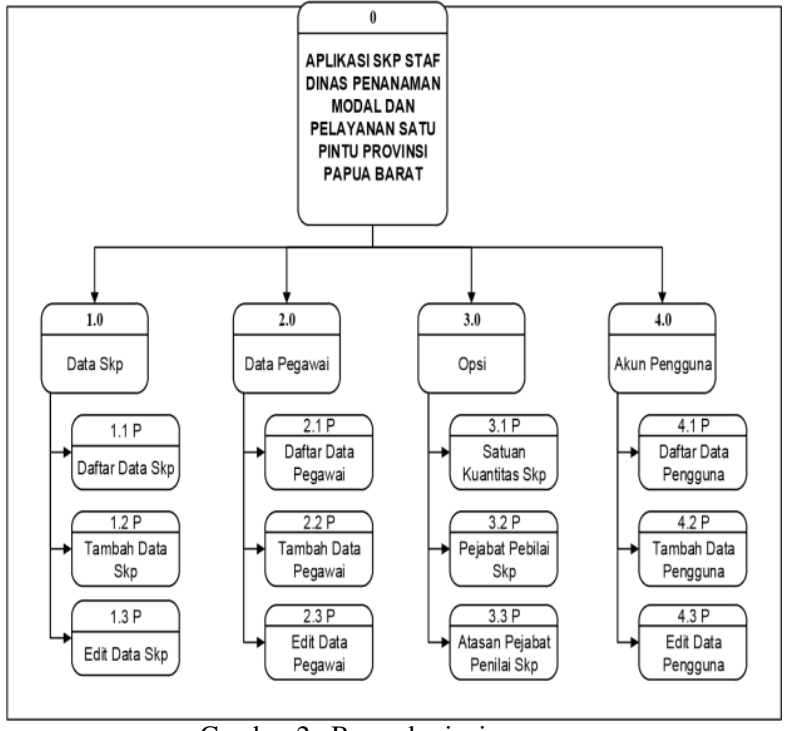

Gambar 2. Bagan berjenjang

c. Data Flow Diagram Level 1

DFD level 1 bertujuan untuk memberikan pandangan mengenai keseluruhan sistem dengan lebih mendalam. Proses-proses utama yang ada akan dipecah menjadi subproses. Adapun DFD level 1 dapat digambarkan sebagai berikut :

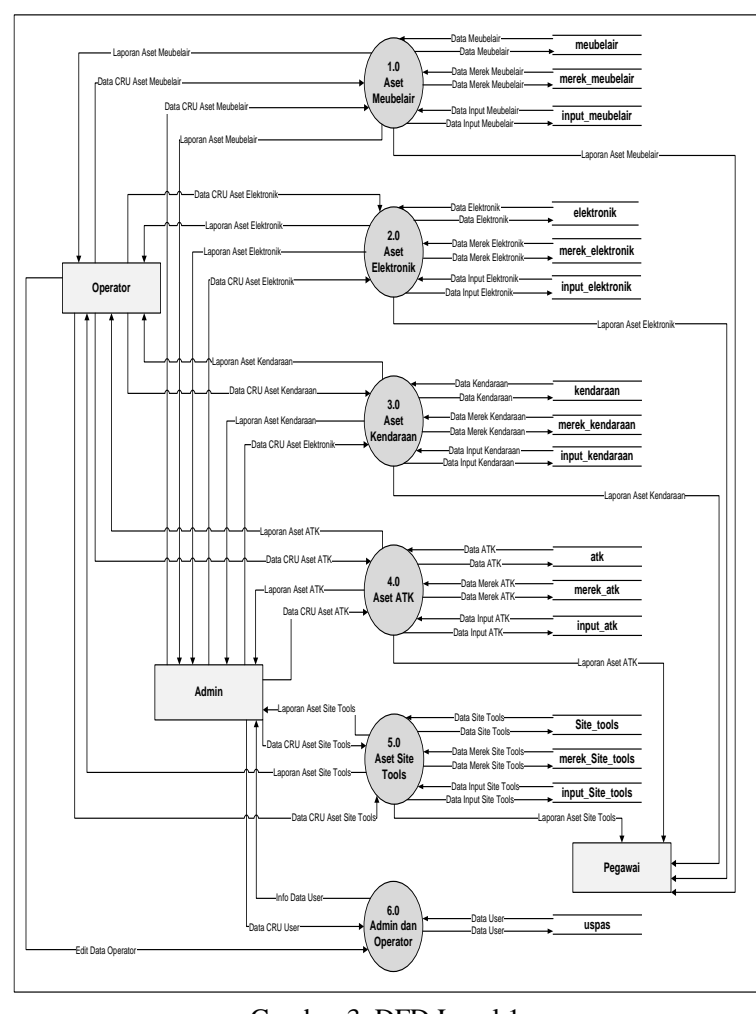

Gambar 3. DFD Level 1

d. Entity-Relationship Diagram (ERD)

Entity Relationship Diagram (ERD) merupakan suatu model untuk menjelaskan hubungan antar data dalam basis data yang berdasarkan objek-objek dasar data yang mempunyai hubungan antar relasi. ERD Aplikasi SKP pada 
Dinas Penanaman Modal dan Pelayanan Terpadu Satu Pintu Provinsi Papua Barat adalah sebagai berikut :



Gambar 4. Relasi ERD

3. Implementasi

Hasil yang diperoleh setelah melewati tahap analisa dan perancangan dapat dimplementasikan pada aplikasi sebagai berikut

a. Tampilan Form Login

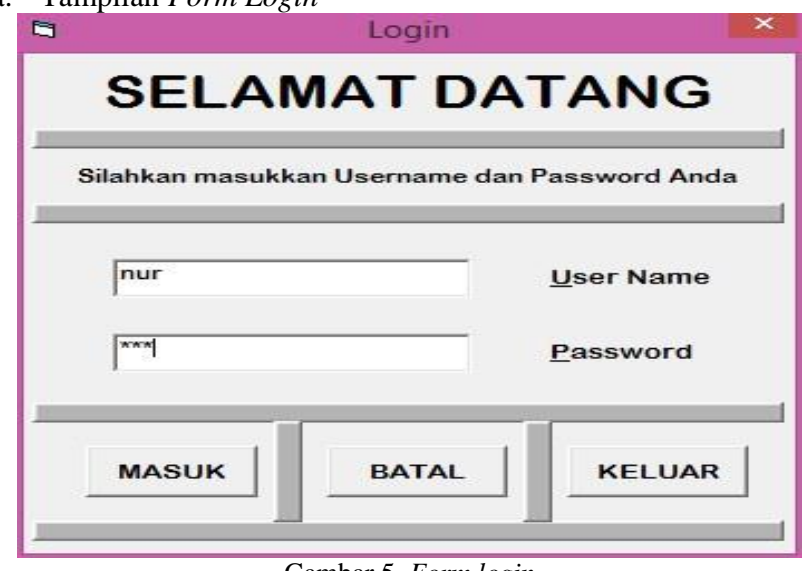

Gambar 5 Form login b. Form Menu Utama Pengguna Level Operator



Setelah Pengguna berhasil melakukan login maka form flash yang terlihat pada Gambar diatas akan di tampilkan terlebih dahulu sebelum pengguna beralih ke Sub-sub form menu utama lainnya.

c. Pesan Konfirmasi Log Out Dari Pengguna Exit.

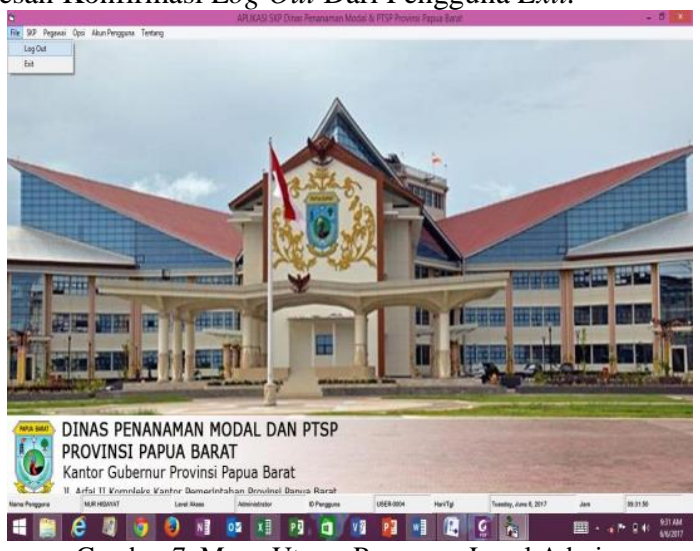

Gambar 7. Menu Utama Pengguna Level Admin.

Pesan konfirmasi untuk Log Out pada Gambar diatas maka akan tampil ketika pengguna yang sedang aktif dalam aplikasi hendak melakukan proses log out dari aplikasi.

d. Tampilan Form Sub Menu SKP

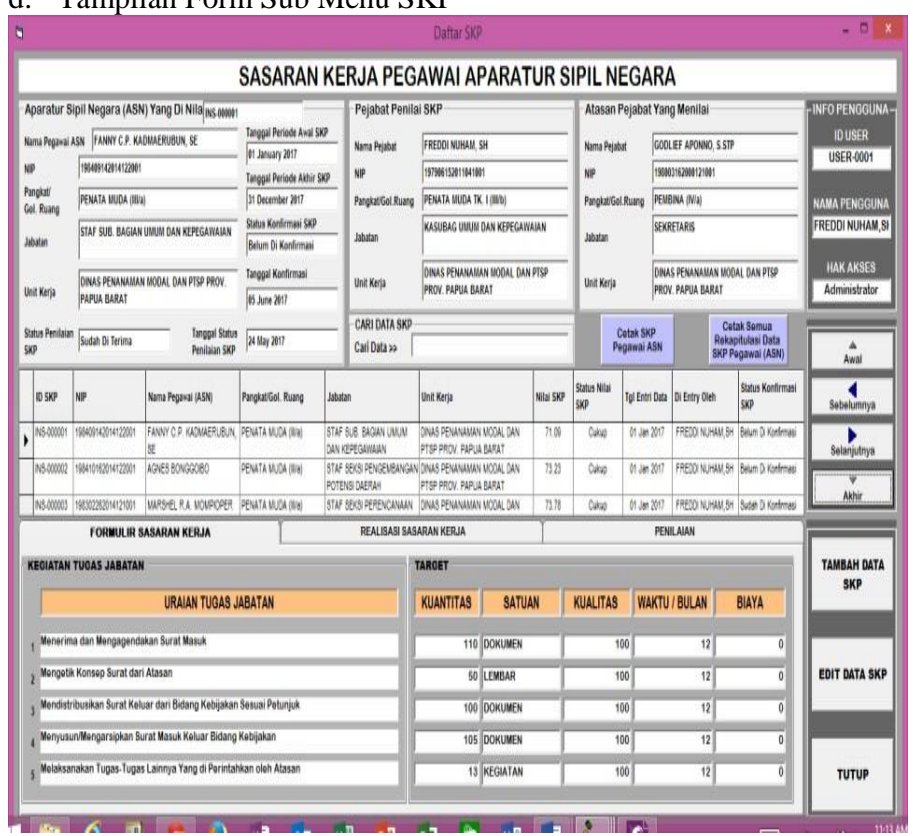

Gambar 8 Sub Menu Daftar SKP pengguna Level Admin dan Operator. 
e. Tampilan Form Sub Menu Opsi

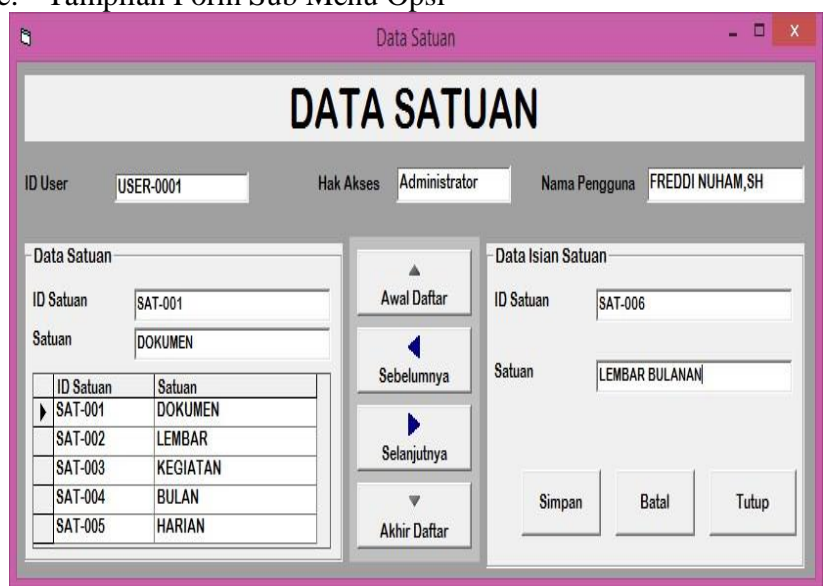

Gambar 9. Sub Menu Tambah Satuan Kuantitas Pengguna Level Admin.

f. Tampilan Form Sub Menu Operator User Level Operator

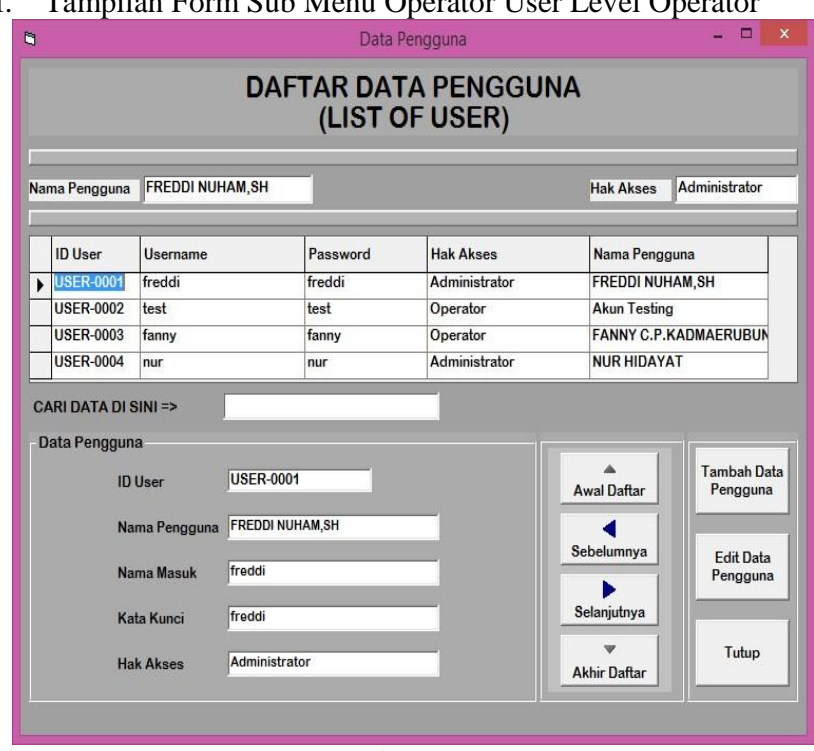

Gambar 10. Sub Menu Daftar Data Pengguna Level Admin

4. Pengujian

Untuk dapat mengetahui apakah Aplikasi SKP pada Dinas Penanaman Modal dan Pelayanan Terpadu Satu Pintu Provinsi Papua Barat perlu dilakukan pengujian terhadap aplikasi. Pengujian aplikasi SKP mengunakan metode blackbox dapat digambarkan sebagai berikut :

Tabel 1. Pengujian Aplikasi SKP Menggunakan Metode blackbox

\begin{tabular}{|c|l|l|c|}
\hline No & Menu/ Button & \multicolumn{1}{|c|}{ Unjuk Kerja } & Keterangan \\
\hline 1 & Menu Login & $\begin{array}{l}\text { Menampilkan menu } \\
\text { SKP meenu Login }\end{array}$ & Berhasil \\
\hline 2 & Menu Admin & $\begin{array}{l}\text { Menampilkan menu } \\
\text { SKP Level Admin }\end{array}$ & Berhasil \\
\hline 3 & $\begin{array}{l}\text { Menu } \\
\text { Operator }\end{array}$ & $\begin{array}{l}\text { Menampilkan menu } \\
\text { aplkasi SKP Level } \\
\text { Admin }\end{array}$ & Berhasil \\
\hline 4 & $\begin{array}{l}\text { Menu Data } \\
\text { SKP }\end{array}$ & $\begin{array}{l}\text { Menampilkan menu data } \\
\text { SKP Pagawai }\end{array}$ & Berhasil \\
\hline 5 & $\begin{array}{l}\text { Menu Data } \\
\text { Opsi }\end{array}$ & $\begin{array}{l}\text { Menampilkan menu Opsi } \\
\text { data satuan SKP }\end{array}$ & Berhasil \\
\hline 6 & $\begin{array}{l}\text { Menu daftar } \\
\text { Data } \\
\text { Pengguna }\end{array}$ & $\begin{array}{l}\text { Menampilkan menu Opsi } \\
\text { data satuan SKP Pegawai }\end{array}$ & Berhasil \\
\hline
\end{tabular}

\section{KESIMPULAN}

Berdasarkan perancangan, analisa dan pengujian pada aplikasi Sasaran Kerja Pegawai dapat diambil beberapa kesimpulan bahwa dengan adanya aplikasi SKP dapat meningkakan kemudahan pegawai meningkatkan efisiensi waktu dan tenaga dalam menyusun dan mengolah data informasi SKP, selain hal tersebut dengan adanya aplikasi SKP jugas dapat memudahkan Dinas Dinas Penanaman Modal dan Pelayanan Terpadu Satu Pintu Provinsi Papua Barat dalam memantau dan meningkatkan kinerja dari pegawainya.

\section{DAFTAR PUSTAKA}

[1] Defta Afriani (2019), Perancangan Knowledge Mangement System Dengan Seci Model Pada Layanan Perbaikan Ac Mobil di Bengkel Agung Motor Cinere Mengunakan VB.Net, Jurnal Informatika SIMANTIK, 4(1), 29-35.

[2] Mulyaningsih (2018), Implementasi Penilaian Prestasi Kerja Pegawai Negeri Sipil, Jurnal Jendela Inovasi Daerah,1(2), 21-36.

[3] Nurul Anjasari, Andy Prasetyo Utomo (2016), Aplikasi Penyusunan Sasaran Kinerja Pegawai Berbasis Web pada DISHUBKOMINFO Kudus, Jurnal Simetris,7(1), 385-390.

[4] Nurul Fuad (2017), Implementasi Visual Basic Net pada Program Retail Produk Hasil Laut pada Toko "KBS" Secara Tunai, Jurnal SPIRIT, 9(1), 17-22.

[5] Sriwiyanti, Effiyaldi (2019), Analisis dan Perancangan Sistem Informasi Administrasi Kinerja Pegawai pada SMA Negeri 11 Kota Jambi, Jurnal Manajemen Sistem Informasi,4(4), 378-388.

[6] Yulita Ananda (2020), Sistem Informasi Aplikasi Penyusunan Sasaran Kerja Pegawai (SKP) pada Kanwil Kementrian Hukum dan Ham Aceh, Jurnal Teknologi Informasi dan Komunikasi,4(2), 67-74. 